\title{
Application of Multi-Tracer Methods to Evaluate Nitrate Sources and Transformation in Sabkha Matti (Saudi Arabia)
}

\author{
Waleed Saeed ${ }^{1, *}$, Orfan Shouakar-Stash ${ }^{1,2,3}$, Andrè Unger $^{1}$, and Warren W. Wood ${ }^{4}$ \\ ${ }^{1}$ Department of Earth and Environmental Science, University of Waterloo, Waterloo, Ontario, N2L \\ 3G1, Canada \\ ${ }^{2}$ Isotope Tracer Technologies Inc, Waterloo, Ontario, N2V 1Z5, Canada \\ ${ }^{3}$ School of Engineering, University of Guelph, Guelph, ON, N1G 2W2, Canada \\ ${ }^{4}$ Department of Earth and Environmental Sciences, Michigan State University, 288 Farm Lane, MI \\ 48824, United States
}

\begin{abstract}
An unusually high concentration of nitrate $\left(\mathrm{NO}_{3}\right)$ ranging between 291 and $6790 \mathrm{mg} / \mathrm{L}$ (as N) was observed during a review of solute data for brine samples from the inland Sabkha Matti. A multi-tracer approach considering water chemistry, stable nitrate isotopes $\left(\delta^{15} \mathrm{~N}\right.$ and $\delta$ ${ }^{18} \mathrm{O}$ ), and the radioactive isotope of hydrogen (tritium, ${ }^{3} \mathrm{H}$ ) was utilized to evaluate the nitrate sources and transformation in this hydrogeological setting. The results suggested that the source of the high nitrate levels is related to a leakage from a manure/septic system near the proximal eastern edge of the Sabkha. Moreover, the impact of Sabkha's characteristics on biological denitrifications was evaluated in this study. The results suggest that denitrification was not a major process in Sabkha Matti. Several factors may contribute to the limitation of denitrification on the brine samples including high dissolved oxygen contents, high salinity and chloride.
\end{abstract}

\section{Introduction}

Concentrations of oxygenated nitrogen species are typically low in geologic brines [1]. However, we observed unusually high concentrations of nitrate $\left(\mathrm{NO}_{3}\right)$ ranging between 764 and $6790 \mathrm{mg} / \mathrm{L}$ (as N) during a review of solute data for brine samples from the inland Sabkha Matti (Fig. 1). Determining the source of this nitrate can play a key role in understanding the process by which Sabkha Matti system was developed, and to better enhance the development of a hydrological budget analysis for the Sabkha, which would be the subject for a future study.

Sabkhas or salt flats or bodies of saline water are ubiquitous features in arid and semiarid areas of the earth. The excess of evaporation over precipitation and shallow groundwater table are critical components for the occurrence of these features. Coastal sabkha represent a discharge area or base level of local and regional groundwater and

\footnotetext{
*Corresponding author : wsaeed@uwaterloo.ca
} 
surface-water systems. Owing to the shallow groundwater table where the capillary rise intersects the surface, evaporation concentrates the solutes to high levels that have the potential to impact the groundwater quality in adjacent aquifers [1]. Within the sabkha, the nitrogen systematics are expected to be relatively simple, as there is no soil, no resident population, no anthropogenic land or water use, and no vegetation [2]. In these environments, atmospheric deposition of nitrogen would be expected to be a major source.

Groundwater can be enriched with nitrate concentrations by several natural and anthropogenic activities. These include atmospheric deposition, bacterial production, mineral fertilisation, leaking septic systems, animal manure, and leakage if the sabkha have contact with adjacent aquifers that have high nitrate contents [3]. To distinguish between different sources of nitrate, various approaches have been adopted. Two of the main successful approaches in nitrate source determination are the use of isotopes and chemical markers. For instance, the isotopic composition of dissolved nitrates $\left(\delta^{15} \mathrm{~N}^{-\mathrm{NO}_{3}}\right)$ has been used extensively to better constrain the sources and fate of nitrate in groundwater [4]. Moreover, a dual isotope approach involving the isotopic composition of nitrogen $\left(\delta^{15} \mathrm{~N}\right)$ and oxygen $\left(\delta^{18} \mathrm{O}\right)$ of nitrate has been proposed when there is a difficulty in differentiating numerous nitrate sources based solely on $\delta^{15} \mathrm{~N}[5,6]$. This is mainly because the $\left(\delta^{18} \mathrm{O}\right)$ isotopic separation of some sources is greater than for $\left(\delta^{15} \mathrm{~N}\right)$ [7]. In this study, the high nitrate concentration of the shallow aquifer system in Sabkha Matti was investigated using a multi-tracer approach considering water chemistry, stable nitrate isotopes $\left(\delta^{15} \mathrm{~N}\right.$ and $\left.\delta^{18} \mathrm{O}\right)$ and the radioactive isotope of hydrogen $\left({ }^{3} \mathrm{H}\right)$. The objective was to identify potential sources and processes controlling nitrate concentrations in the shallow aquifer system at Sabkha Matti.

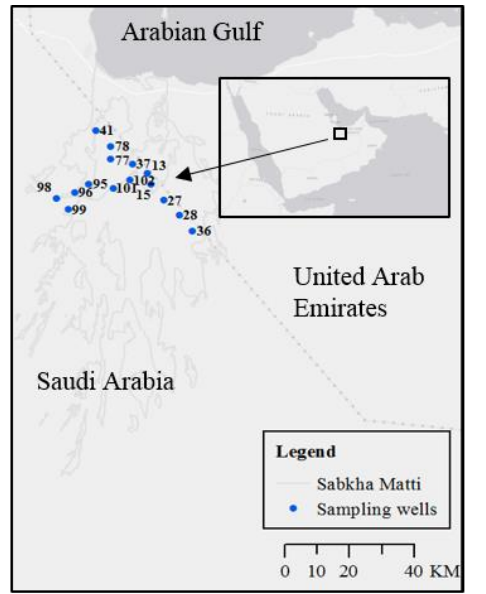

Fig. 1. Map showing the location of Sabkha Matti and sampling wells.
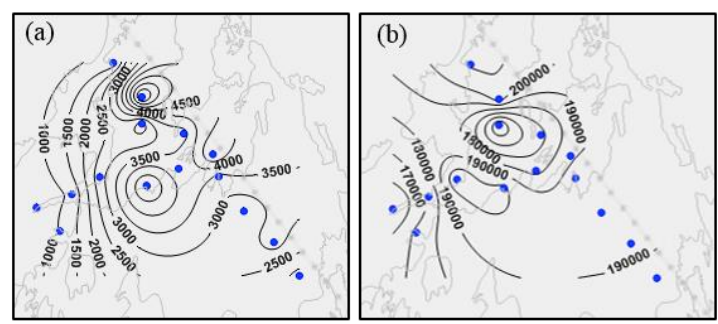

Fig. 2. Contour map of (a) nitrate and (b) chloride concentration values in Sabkha Matti aquifer.

\section{Hydrogeological framework and sample collection}

The aquifer system in Sabkha Matti composes mainly of fluvial deposits. The vast majority of these fluvial sediments were accumulated during the Holocene [8], in a paleo-deltaic depositional environment formed by the $\sim 140 \mathrm{~m}$ rises of the Gulf in the last 10,000 years, combined with a huge source of continental fluvial sediments derived from a large drainage basin. Sabkha sediments (halite, gypsum, and perhaps some anhydrite) have developed on and near the surface as a result of a groundwater capillary fringe intersecting the land surface and groundwater evaporation concentrating the salts. It is proposed that the fluvial 
sequence of Holocene sediments on which the inland sabkha has developed be given the name Sabkha Matti aquifer (SMA) because of its extensive development within Sabkha Matti area. SMA is underlain by the Dam aquiclude which is considered Early to Middle Miocene varicolored marl and clay with minor sandstone and chalky limestone. Groundwater in the unconfined SMA generally flows from upland areas in the south, west, and east toward the regional discharge area along the Arabian Gulf. The climate in the region today is arid and has only two recognisable seasons: a prolonged dry summer from April to November, when temperature may exceed $50^{\circ} \mathrm{C}$; and a short winter from December to March, where temperatures may fall to below $13{ }^{\circ} \mathrm{C}$. The mean annual rainfall taken over a fourteen-year period is about $29 \mathrm{~mm}$ [9]. Almost $90 \%$ of this rainfall occur during the winter season and is commonly accompanied by a strong northerly wind (Shamal). The majority of the rainfalls have been observed to infiltrate the surface quickly and become groundwater recharge, which is counterintuitive for most arid regions, where recharge to groundwater is usually a very small percentage of rainfall [10]. However, most of this groundwater recharge is eventually lost again to evaporation during the dry seasons.

Holes for 15 shallow piezometers $(<7 \mathrm{~m})$ were drilled between 1 and $2 \mathrm{~m}$ below the water table by using Geoprobe, Model 6620DT, and direct push equipment. Groundwater samples were collected using a plastic bailer. Analyses of the groundwater samples for electrical conductivity (EC), $\mathrm{pH}$, temperature, and dissolved oxygen content were carried out in the field using a portable HQ40d meter (Hach Ltd.). Field measurements of alkalinity were made using a Hach field titration kit and expressed as $\mathrm{mg} / \mathrm{L}$ of equivalent $\mathrm{HCO}_{3}$. Analyses of major ions were performed by ALS laboratory group, Waterloo, Canada. Analyses for the stable and radioisotopes were performed at $\mathrm{IT}^{2}$ lab, Waterloo, Canada.

\section{Results and discussion}

\subsection{Chemical composition and nitrate concentration}

Field measurements and chemical composition data of the collected brine samples are presented in Table 1.

Table 1. Stable, radioactive isotopes and solute chemistry of brine samples from Sabkha Matti.

The measurement of electrical conductivity (EC) indicated that the collected brine

\begin{tabular}{|c|c|c|c|c|c|c|c|c|c|}
\hline Sample ID & $\begin{array}{c}E C \\
(\mathrm{mS} / \mathrm{cm})\end{array}$ & $\begin{array}{c}\text { Temp. } \\
\left({ }^{\circ} \mathrm{C}\right)\end{array}$ & $\mathrm{pH}$ & $\begin{array}{c}\mathrm{DO} \\
(\mathrm{mg} / \mathrm{L})\end{array}$ & $\begin{array}{c}\mathrm{Cl} \\
(\mathrm{mg} / \mathrm{L})\end{array}$ & $\begin{array}{c}\mathrm{NO}_{3} \\
(\mathrm{mg} / \mathrm{L})\end{array}$ & $\begin{array}{c}\delta^{15} \mathrm{~N} \\
\% 0\end{array}$ & $\begin{array}{c}\delta^{18} \mathrm{O} \\
\% \mathrm{o}\end{array}$ & ${ }^{3} \mathrm{H}$ \\
\hline 13 & 331.8 & 32.1 & 5.77 & 2.62 & 188000 & 5090 & 5.5 & 1.9 & 0.8 \\
\hline 15 & 341.6 & 30.8 & 6.26 & 4.09 & 196000 & 3310 & 11.6 & 1.6 & 1.6 \\
\hline 27 & 340 & 24.7 & 6.28 & 6.07 & 192000 & 2630 & 8.9 & 16.9 & 1.2 \\
\hline 28 & 346.8 & 27.9 & 6.32 & 8.24 & 197000 & 3240 & 9.3 & 9.9 & 1.5 \\
\hline 36 & 317.8 & 24.6 & 6.52 & 6.78 & 181000 & 1780 & 9.1 & 23.0 & 0.8 \\
\hline 37 & 296.2 & 27.7 & 6.74 & 7.11 & 167000 & 3290 & 8.5 & 18.7 & 0.8 \\
\hline 41 & 339.2 & 28.4 & 6.75 & 6.35 & 211000 & 1130 & 13.4 & 9.7 & 0.9 \\
\hline 77 & 228 & 28.5 & 7.31 & 5.39 & 139000 & 2210 & 9.2 & 12.7 & 1.9 \\
\hline 78 & 344.8 & 28.6 & 6.52 & 6.55 & 206000 & 6790 & 12.8 & 20.0 & 2.0 \\
\hline 95 & 332 & 31.3 & 6.59 & 0.81 & 209000 & 2800 & 9.3 & 11.7 & 0.8 \\
\hline 96 & 328.4 & 28.6 & 6.34 & 2.99 & 169000 & 1090 & 5.8 & 4.3 & 1.0 \\
\hline 98 & 282 & 29.2 & 6.84 & 2.34 & 150000 & 764 & 10.8 & 6.2 & 1.2 \\
\hline 99 & 301 & 27.4 & 6.48 & 2.97 & 173000 & 1030 & 8.7 & 4.4 & 0.8 \\
\hline 101 & 341.6 & 29.4 & 5.89 & 3.7 & 202000 & 5170 & 10.5 & 16.8 & 0.9 \\
\hline 102 & 316.6 & 29.9 & 6.28 & 3.67 & 177000 & 3660 & 10.3 & 2.2 & 0.8 \\
\hline
\end{tabular}

samples have significantly high values which ranged from 228 to $347 \mu \mathrm{S} / \mathrm{cm}$ (mean 319 $\mu \mathrm{S} / \mathrm{cm})$. As expected from a sabkha environment, the brine samples from Sabkha Matti 
were dominated by a $\mathrm{Na}-\mathrm{Cl}$ chemistry, with extremely high total dissolve solids concentrations. Average discharge temperature was measured to be around $28.6{ }^{\circ} \mathrm{C}$. The $\mathrm{pH}$ ranged from 5.8 to 7.3 (mean 6.5) and DO ranged from 0.8 to $8.2 \mathrm{mg} / \mathrm{L}$ (mean $4.6 \mathrm{mg} / \mathrm{L}$ ). When chloride and nitrate concentration data are placed according to well location, significant differences in concentrations were observed. Concentrations were highest in wells located at the proximal eastern edge of Sabkha Matti, and they tend to decrease elsewhere (Fig. 2). This observation suggests the sources of nitrate to be near the eastern edge of Sabkha Matti.

\subsection{Isotope composition and source of nitrate}

The isotope values of the collected brine samples are shown in Table 1 . The $\delta^{15} \mathrm{~N}$ and $\delta^{18} \mathrm{O}$ values ranged from $5.5 \%$ o to $13.3 \%$ ( mean $=9.5 \%$ ), and from $1.5 \%$ to $22.9 \%$ o $($ mean $=$ $10.6 \%$ ), respectively. These isotope values were plotted (Fig. 4), in comparison to a measured value of direct local precipitation and typical values of major nitrate sources from the literatures $[7,11]$. The majority of the brine samples $(73 \%)$ fall directly into the manure $\&$ septic waste range. The isotopic compositions of the remaining $(27 \%)$ samples might be a result of mixing and dilution between the manure/septic source and local precipitations. This can be supported by utilizing nitrate / chloride ratios. Chloride $\left(\mathrm{Cl}^{-}\right)$generally behaves as a conservative solute in groundwater that is resistant to physical, chemical and biological processes. Thus, a decrease in $\mathrm{Cl}^{-}$concentration along the groundwater flow path may provide a practical indication of mixing and dilution. A gradual decline along the flow direction was observed for $\mathrm{Cl}^{-}$and $\mathrm{NO}_{3}$ (Fig. 2). This positive correlation in concentration's reduction indicates that mixing and dilution processes had a major effect on $\mathrm{NO}_{3}$ transport, and thus its isotopic composition. In addition, ages of the brine samples were identified by measuring tritium $\left({ }^{3} \mathrm{H}\right)$ levels. The presence of ${ }^{3} \mathrm{H}$ in groundwater can provide information on modern groundwater recharge to an aquifer [12]. The majority of samples from SMA contained tritium above the detection limit of 0.8 T.U. The presence of this tritium indicates recent local rainfalls as the major source of water in Sabkha Matti. In conclusion, a compilation of chemistry and isotope data suggested that the unusually high concentration of nitrate in SMA must be due to a leakage from a manure/septic source near the proximal eastern edge of the Sabkha and the major source of water to be from recent preciptations.

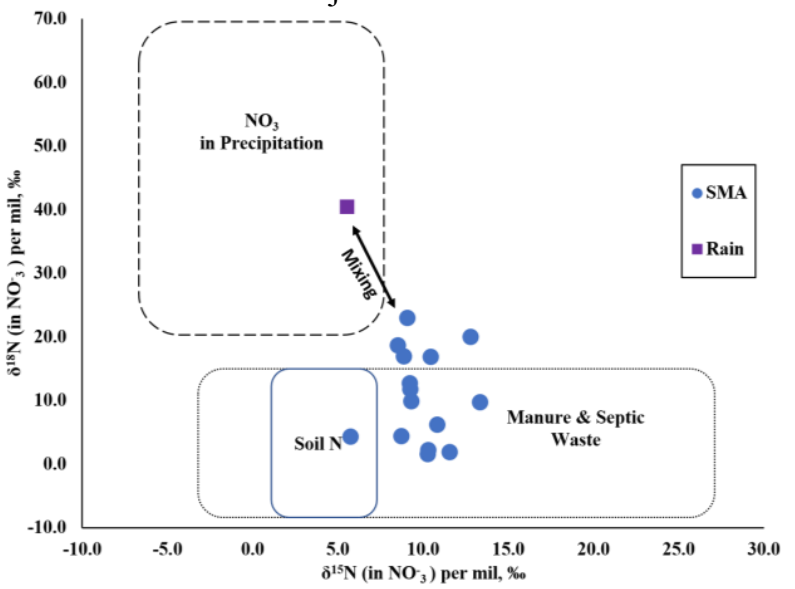

Fig. 3. Graph of the observed $\delta^{15} \mathrm{~N}$ and $\delta^{18} \mathrm{O}$ values of nitrate in Sabkha Matti with a general depiction of the normal range values for the dominant sources of nitrate from [1]. 


\subsection{Assessment of potential denitrification in Sabkha system}

Biological denitrification involves the bacterially mediated reduction of $\mathrm{NO}_{3}$ via a multistep process to dinitrogen gas. This biological process is well-known as being the most attractive process for the reduction of nitrate from groundwater [13]. The information on denitrification under extreme conditions, such as Sabkha environment, is limited. Thus, the combination of chemical data with stable isotopes of nitrate were investigated to evaluate the impact of Sabkha's characteristics on denitrification. Correlation between the nitrate concentrations and the isotopic compositions of nitrates can provide information on denitrification. If denitrification had occurred, the reduction of nitrate to nitrite would exhibit significant $\delta^{15} \mathrm{~N}$ and $\delta^{18} \mathrm{O}$ discriminations in accordance with decreasing nitrate concentrations. This is because during denitrification, the lighter isotopes ${ }^{14} \mathrm{~N}$ and ${ }^{16} \mathrm{O}$ in the bearing nitrate is consumed more rapidly than the bearing heavy isotopes ${ }^{15} \mathrm{~N}$ and ${ }^{18} \mathrm{O}$ [14]. This negative correlation between the nitrate concentration and $\delta^{15} \mathrm{~N}$ and $\delta^{18} \mathrm{O}$ was not observe in the brine samples from SMA (Fig. 4). Accordingly, we concluded that denitrification may not be a major process in SMA. Several factors may contribute to the limitation of denitrification on the brine samples from SMA. First, an average dissolved oxygen of $4.6 \mathrm{mg} / \mathrm{L}$ was measured in the brine samples, indicating oxidized conditions which does not support denitrification. Second, salinities of the collected samples were extremely high (average $=275,000 \mathrm{mg} / \mathrm{L}$ ). These salinities are believed to be key factors in reducing the potential of denitrification, because some enzymes will be suppressed as reported [16]. Third, the presence of high chloride concentration in the samples (average = $188,800 \mathrm{mg} / \mathrm{L}$ ), may have significantly limit the biological denitrification process. Similarly, [13] has reported an inverse relationship between the presence of high chloride concentration and biological denitrification, where the volumetric rates of nitrate removal by denitrification were reduced by a factor of ten between chloride levels of 4.8 to $96.7 \mathrm{~g} / \mathrm{L}$.

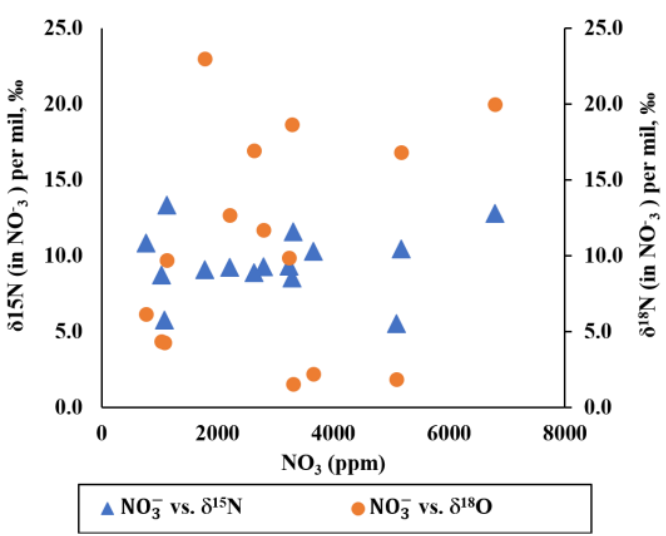

Fig. 4. Lack of negative correlation between nitrate concentrations and isotopic compositions $\delta^{15} \mathrm{~N}$, $\delta^{18} \mathrm{O}$ of nitrate in brine samples from Sabkha Matti, indicating insignificant denitrification.

\section{References}

1. P. Sonnenfeld, Brines and Evaporites, p. 613 (Academic Press, New York, 1984)

2. W.W. Wood, J.K. Böhlke, Groundwater, 55, 2 (2017)

3. G. Bordeleau, M.M. Savard, R. Martel, G. Ampleman, S. Thiboutot, J. Contam. Hydrol. 98, 3-4 (2008)

4. S. Panno, K.C. Hackley, H. Hwang, W. Kelly, Chem. Geol. E 179, 1-4 (2001) 
5. D. Xue, J. Botte, B. De Baets, F. Accoe, A. Nestler, P. Taylor, P. Boeckx, Water Res. E 43, 5 (2009)

6. R. Aravena, B. Mayer, Environmental isotopes in biodegradation and bioremediation, p. 203-46 (CRC Press, 2010)

7. C. Kendall, Isotope tracers in catchment hydrology, p. 519-576 (Elsevier, 1998)

8. W.W. Wood, W.E. Sanford, S. Al Habshi, Geol. Soc. Am. Bull. E 114, 3 (2002)

9. Ministry of presidential affairs, United Arab Emirates: National Center of Meteorology (2018)

10. W.E. Sanford, W.W. Wood, Hydrogeol. J. E 9, 4 (2001)

11. S.D. Wankel, C. Kendall, A. Paytan, J. Geophys. Res. Biogeosci. E 114, G1 (2009)

12. P.A. Thompson, N.A. Kwamena, M. Ilin, M. Wilk, I.D. Clark, J. Environ. Radiact. E 140, 105-113 (2015)

13. A.S. Ucisik, M. Henze, Water Sa. E 30, 2 (2004)

14. J. Granger, D.M. Sigman, M.F. Lehmann, P.D. Tortell, Limnol. Oceanogr. E 53, 6 (2008)

15. Z. Wang, M. Gao, J. Wei, K. Ma, J. Pei, J. Zhang, S. Yu, J. Taiwan Ins. Chem. Eng. E 68, 275-280 (2016) 